\title{
Comparison of Service Quality, Customer Satisfaction and Behavioral intentions across the Various Formats (Supermarket, Hypermarket \& Departmental Store) in India
}

\author{
Dr. Ajmer Singh \\ Assistant Professor and Head (MBA) \\ Kurukshetra University Post Graduate Regional Centre, Jind, Haryana, India \\ E-mail: ajmer.singh@kuk.ac.in
}

Received: March 28, 2013 Accepted: April 14, 2013

doi:10.5296/ber.v3i1.3443 URL: http://dx.doi.org/10.5296/ber.v3i1.3443

\begin{abstract}
This study is conducted to understand the level of service quality, customer satisfaction and behavioral intentions across the various formats like super market, Hypermarket and Departmental store in India. In this study seven stores from organized sector are chosen and they are further divided into various formats like super market, Hypermarket and Departmental store. In this study a sample size of 600 customers is chosen and from which 540 completely filled in questionnaires are received. This gives a response rate of $90 \%$. The statistical analysis was done through descriptive statistics and one way ANOVA. From the findings there exists a statistical significant difference in many aspects of service quality and customer satisfaction, but there is

No difference in the dimensions of behavioral intentions in these formats. Hence the researcher suggests the implications for the managers on the basis of conclusions and findings of the study.
\end{abstract}

Keywords: Service Quality, Satisfaction, Behavioral Intentions, Supermarket, Hypermarket \& Departmental Store etc.

\section{Introduction}

In India organized retailing is growing at a fast rate. Today shoppers can shop for goods and services from large variety of stores. Nowadays stores are divided into many categories on the basis of product variety, size of store, number of assortments etc.(Berman \& Evans, 1995). In 
this study we will study three types of formats namely Super market, Hyper Market and Departmental Stores. Now these three types are defined as.

a) Supermarkets: These stores operate in an area of approximately 800-5000 square feet. These stores offer food, Laundry and household products. These stores operate through self-service, low cost, low margins and high volume operators, e.g. Reliance Fresh, Food World, Food bazaar etc. On the other side in the western supermarket, these stores operate in an area of 8000-20000 square foot.

b) Hypermarkets: These are the largest stores offering food as one of their category of items. In India these stores are covering an area of 40,000 to 75,000 square feet. These stores contain apparel, cosmetics, furniture, electronic as well as food items, e.g. Big Bazaar. On the other hand in the international market these stores cover an area of 80,000-2, 20,000 square feet.

c) Departmental Stores: In the departmental store, there are many product lines with each line operated as a separate department and they are managed by specialist merchandiser.

Now as all these formats are coming in organized retail formats. So it becomes important to understand the quality aspects among these formats.

\section{Review of Literatures}

From the review of literatures it is found that services are very important for any sector in the economy. Now (Robinson, 1999) defined service quality as customers' attitude or judgment about the superiority of any service. In 1990s Zeithaml, Parasuraman \& Berry introduced the concept of customer expectations with performance of the services. Teas argued further deriving a comparison of performance with ideal standards (Robinson, 2000; Lee et al; 2000). Many tools were proposed by many authors to measure the service quality. The most popular scale named as SERVQUAL the most popular was proposed by Parasuraman, Zeithaml \& Berry in 1988 and further used by (Franceschini, Cignetti \& Caldara, 1998; Robinson 1999; Caruana, Money \& Berthon, 2000; Lee et al. 2000). SERVQUAL is based on the measurement of service quality by calculating the gap between what the customers expect and what they perceive in quality. Another scale named as SERVPERF developed by Cronin and Taylor in 1992, measures service quality through performance only. Another model is Normed Quality proposed by Teas in 1993. This model measures the service quality by the gap between perceived performance and the ideal amount of a feature, rather customers' expectations as proposed by SERVQUAL. In this study scale developed by Dhabolkar, Thorpe and Rentz (1996) developed RSQS (Retail Service Quality Scale) to measure the service quality among the retail stores was used for the study. This scale is designed for the use in studying retail businesses that offer a mix of goods and services, for assessing levels of service quality, and the necessary changes required in the services. This scale consists of 28 items and five dimensions: Physical aspects (6 items), Reliability (5), Personal Interaction (9), Problem Solving (3), and Policy (5). The first three dimensions have sub-dimensions: Physical aspects (i.e. appearance and convenience), Reliability (i.e. promises and doing it right), and personal interactions (i.e. inspiring confidence and courteousness/helpfulness). A five point likert scale starting from strongly disagree (1) to strongly agree (5) response was used.

\section{Research Methodology}

This study is designed to compare the service quality, customer satisfaction and behavioral 
intentions aspects among the various formats like Supermarket, Hypermarket \& departmental store. For this study a sample size of 600 customers was chosen from three states of India which are Delhi, Haryana (Gurgaon \& Faridabad) and U.P. (Noida \& Ghaziabad). The total 540 filled-in Questionnaires are received from the customers. It provided a response rate of 90\%. The data was analyzed through Descriptive statistics, Frequency Method and one way ANOVA.

\subsection{Objectives of the Study}

The following objectives are being formulated for the study.

To find out the level of Service Quality, Customer Satisfaction \& behavioral Intentions among the various formats like Supermarket, Hypermarket \& Departmental Stores.

To compare the level of Service Quality, Customer Satisfaction \& Behavioral Intentions among the various formats like Supermarket, Hypermarket \& Departmental Stores.

\subsection{Hypotheses of the Study}

There exists a significant difference among the aspects of service quality in various formats like Supermarket, Hypermarket \& Departmental Stores.

There exists a significant difference among the aspects of customer satisfaction in various formats like Supermarket, Hypermarket \& Departmental Stores.

There exists a significant difference among the aspects of behavioral Intentions in various formats like Supermarket, Hypermarket \& Departmental Stores.

\section{Data Interpretation \& Data Analysis}

This analysis is carried out to find out the difference among the different variables in various formats among the organized retail outlets. This study is being carried out from seven types organized stores and these belong to different types of formats in organized stores. The seven stores Reliance Fresh, Big Bazaar, Vishal Mega mart, Westside, Shopper Stop, and Ebony.

Table 1

\begin{tabular}{|l|l|l|}
\hline S. No. & Name of Store & Type of Format \\
\hline 1 & Reliance Fresh & Super Market \\
\hline 2 & Big Bazaar & Hyper Market \\
\hline 3 & Vishal Mega Mart & Hyper Market \\
\hline 4 & Spencer's & Hyper Market \\
\hline 5 & Shopper Stop & Departmental Store \\
\hline 6 & Westside & Departmental Store \\
\hline 7 & Ebony & Departmental Store \\
\hline
\end{tabular}

In this study a total of 42 stores selected from which the data is being collected.

\section{Frequency Table}


4.1 Number of Customers from Different Formats (Super Market, Hyper Market \& Departmental Stores)

Table 2

\begin{tabular}{|l|l|l|l|l|}
\hline \multicolumn{2}{|l|}{ Frequency } & Percentage & Cumulative Percentage \\
\hline Super Market & Delhi & 50 & 58.8 & 58.8 \\
\cline { 2 - 5 } & Haryana & 19 & 22.3 & $81.1 \%$ \\
\cline { 2 - 5 } & U.P. & 16 & 18.9 & 100.0 \\
\cline { 2 - 5 } & Total & 85 & 100.0 & \\
\hline Hyper Market & Delhi & 77 & 30.2 & 30.2 \\
\cline { 2 - 5 } & Haryana & 69 & 27.1 & 57.3 \\
\cline { 2 - 5 } & U.P. & 109 & 42.7 & 100.0 \\
\cline { 2 - 5 } & Total & 255 & 100.0 & \\
\hline \multirow{3}{*}{$\begin{array}{l}\text { Separtmental } \\
\text { Store }\end{array}$} & Delhi & 38 & 19.0 & 19.0 \\
\cline { 2 - 5 } & Haryan & 111 & 55.5 & 74.5 \\
\cline { 2 - 5 } & U.P. & 51 & 25.5 & 100.0 \\
\cline { 2 - 5 } & Total & 200 & 100.0 & \\
\hline
\end{tabular}

From the table 2, it is found that there are three types of formats in which the various organized outlets have been divided. These are supermarket, hypermarket and departmental stores. From the table, it is found that there are 85 customers from three states Delhi, Haryana and U.P. and 255 customers from supermarket and 200 customers from departmental stores.

\subsection{Age-wise Distribution of Customers from Different Formats (Super Market, Hyper Market \& Departmental Stores)}

Table 3

\begin{tabular}{|c|c|c|c|c|}
\hline \multicolumn{2}{|c|}{ Name of the format } & Frequency & Percentages & Cumulative Percentage \\
\hline \multirow[t]{5}{*}{ Super Market } & 20-to-25 years & 31 & 36.5 & 36.5 \\
\hline & 25 -to-35 years & 31 & 36.5 & 72.9 \\
\hline & 35-to-45 years & 6 & 7.1 & 80.0 \\
\hline & Above 45 years & 17 & 20.0 & 100.0 \\
\hline & Total & 85 & 100.0 & \\
\hline \multirow[t]{5}{*}{ Hyper Market } & 20-to-25 years & 61 & 23.9 & 23.9 \\
\hline & 25 -to-35 years & 117 & 45.9 & 69.8 \\
\hline & 35-to-45 years & 46 & 18.0 & 87.8 \\
\hline & Above 45 years & 31 & 12.2 & 100.0 \\
\hline & $\overline{\text { Total }}$ & 255 & 100.0 & \\
\hline \multirow{5}{*}{$\begin{array}{l}\text { Departmental } \\
\text { Store }\end{array}$} & 20-to-25 years & 46 & 23.0 & 23.0 \\
\hline & 25 -to-35 years & 82 & 41.0 & 64.0 \\
\hline & 35-to-45 years & 32 & 16.0 & 80.0 \\
\hline & Above 45 years & 40 & 20.0 & 100.0 \\
\hline & Total & 200 & 100.0 & \\
\hline
\end{tabular}

From the table 3 , it is found that there are four age groups in which customers are divided. In supermarket the maximum customers are in the age group between 20-to-25 and 25-to-35. In hypermarket it is found that 117 customers belong to 25-to-35 years of age and next 61 customers are in the age group between 20-to-25 years. In the departmental stores there are 82 customers in the age group between 25-to-35 years and it is followed by 46 customers in 
20-to-25 years of age group.

4.3 Category-wise Distribution of Customers across Various Formats (Super Market, Hyper Market \& Departmental Stores)

Table 4

\begin{tabular}{|c|c|c|c|c|}
\hline \multicolumn{2}{|c|}{ Name of the format } & Frequency & Percentages & \begin{tabular}{|l|} 
Cumulative \\
Percentages
\end{tabular} \\
\hline \multirow{3}{*}{ Super Market } & Male & 53 & 62.4 & 62.4 \\
\hline & Female & 32 & 37.6 & 100.0 \\
\hline & Total & 85 & 100.0 & \\
\hline \multirow{3}{*}{ Hyper Market } & Male & 169 & 66.3 & 66.3 \\
\hline & Female & 86 & 33.7 & 100.0 \\
\hline & Total & 255 & 100.0 & \\
\hline \multirow{3}{*}{\begin{tabular}{|l|} 
Departmental \\
Store
\end{tabular}} & Male & 121 & 60.5 & 60.5 \\
\hline & Female & 79 & 39.5 & 100.0 \\
\hline & Total & 200 & 100.0 & \\
\hline
\end{tabular}

From the table 4, it is found that in super market out of total 85 customers, 53 are male and 32 female. In hypermarket, it is found that out of 255 customers, there are 169 male and 86 female. In departmental stores out of a total 200 customers, it is found that there are 121 male and 79 female.

4.4 Customers Education Category across Various Formats (Super Market, Hyper Market \& Departmental Stores)

Table 5

\begin{tabular}{|l|l|l|l|l|}
\hline Name of the format & & & Cumulative \\
& & Frequency & Percentage & Percentage \\
\hline Super Market & Matriculation & 08 & 9.4 & 9.4 \\
\cline { 2 - 5 } & Diploma & 06 & 7.1 & 16.5 \\
\cline { 2 - 5 } & Degree & 37 & 43.5 & 60.0 \\
\cline { 2 - 5 } & Master Degree & 26 & 30.6 & 90.6 \\
\cline { 2 - 5 } & Ph.D & 05 & 5.9 & 96.5 \\
\cline { 2 - 5 } & Others & 03 & 3.5 & 100.0 \\
\cline { 2 - 5 } & Total & 85 & 100.0 & \\
\hline Hyper Market & None & 06 & 2.4 & 2.4 \\
\cline { 2 - 5 } & Matriculation & 14 & 5.5 & 7.8 \\
\cline { 2 - 5 } & Diploma & 35 & 13.7 & 21.6 \\
\cline { 2 - 5 } & Degree & 79 & 31.0 & 52.5 \\
\cline { 2 - 5 } & Master Degree & 109 & 42.7 & 95.3 \\
\cline { 2 - 5 } & Ph.D & 02 & 3.8 & 96.1 \\
\cline { 2 - 5 } & Others & 10 & 3.9 & 100.0 \\
\cline { 2 - 5 } & Total & 255 & 100.0 & \\
\hline \multirow{5}{*}{\begin{tabular}{l} 
Store \\
\hline \multirow{5}{*}{ Departmental }
\end{tabular}} & Matriculation & 04 & 2.0 & 2.0 \\
\cline { 2 - 5 } & Diploma & 19 & 9.5 & 11.5 \\
\cline { 2 - 5 } & Degree & 90 & 45.0 & 56.5 \\
\cline { 2 - 5 } & Master Degree & 65 & 32.5 & 89.0 \\
\cline { 2 - 5 } & Ph.D & 07 & 3.5 & 92.5 \\
\hline
\end{tabular}




\begin{tabular}{|l|l|l|l|l|}
\hline \multirow{2}{*}{} & Others & 15 & 7.5 & 100.0 \\
\cline { 2 - 5 } & Total & 200 & 100.0 & \\
\hline
\end{tabular}

From the table 5, it is found that in supermarket 37 customers are degree holders And 26 customers are having a master degree. In case of hypermarket, it is found that 109 customers are having a master degree and 79 customers are having a bachelor degree. It is found from the table that in departmental stores 90 customers are having a bachelor degree and further it is followed by 65 customers having a master degree.

\subsection{Customers Income Category across Various Formats (Super Market, Hyper Market \& Departmental Stores)}

Table 6

\begin{tabular}{|c|c|c|c|c|}
\hline \multicolumn{2}{|c|}{ Name of the format } & Frequency & Percent & $\begin{array}{l}\text { Cumulative } \\
\text { Percentage } \\
\end{array}$ \\
\hline \multirow[t]{7}{*}{ Super Market } & \multirow{7}{*}{$\begin{array}{l}\text { Up-To-15,000 } \\
15,001 \text {-to-30,000 } \\
30,001 \text {-to-45,000 } \\
45,001 \text {-to-60,000 } \\
60,001 \text {-to-75,000 } \\
\text { Above 75,000 } \\
\text { Total }\end{array}$} & 20 & 23.5 & 23.5 \\
\hline & & 29 & 34.1 & 57.6 \\
\hline & & 17 & 20.0 & 77.6 \\
\hline & & 07 & 8.2 & 85.9 \\
\hline & & 07 & 8.2 & 94.1 \\
\hline & & 05 & 5.9 & 100.0 \\
\hline & & 85 & 100 & \\
\hline \multirow[t]{7}{*}{ Hyper Market } & \multirow{7}{*}{$\begin{array}{l}\text { Up-To-15,000 } \\
15,001 \text {-to-30,000 } \\
30,001 \text {-to-45,000 } \\
45,001 \text {-to-60,000 } \\
60,001 \text {-to-75,000 } \\
\text { Above 75,000 } \\
\text { Total }\end{array}$} & 30 & 11.8 & 11.8 \\
\hline & & 87 & 34.1 & 45.9 \\
\hline & & 49 & 19.2 & 65.1 \\
\hline & & 28 & 11.0 & 76.1 \\
\hline & & 19 & 7.5 & 83.5 \\
\hline & & 42 & 16.5 & 100.0 \\
\hline & & 255 & 100.0 & \\
\hline \multirow{7}{*}{$\begin{array}{l}\text { Departmental } \\
\text { Store }\end{array}$} & \multirow{7}{*}{$\begin{array}{l}\text { Up-To-15,000 } \\
15,001 \text {-to-30,000 } \\
30,001 \text {-to-45,000 } \\
45,001 \text {-to-60,000 } \\
60,001 \text {-to-75,000 } \\
\text { Above 75,000 } \\
\text { Total }\end{array}$} & 34 & 17.0 & 17.0 \\
\hline & & 46 & 23.0 & 40.0 \\
\hline & & 52 & 26.0 & 66.0 \\
\hline & & 25 & 12.5 & 78.5 \\
\hline & & 16 & 8.0 & 86.5 \\
\hline & & 27 & 13.5 & 100.0 \\
\hline & & 200 & 100.0 & \\
\hline
\end{tabular}

In analyzing the income category, it is found from the table 5, in supermarket 29 customers belong to income group between (15001-to-30,000) and it is followed by the next 20 customers in the income category up-to 15,000 . In hypermarket we found that 87 customers are in the income category between $(15,001-$ to-30,000) and it is followed by 49 customers in the income category between (30,001-to-45,000). In departmental stores, we found that 52 customers are in the income category between $(30,001-$ to- 45,000$)$ followed by 46 customers in the income category between (15001-to-30,000).

4.6 Customers Marital Status across Various Formats (Super Market, Hyper Market \& Departmental Stores)

Table 6 


\begin{tabular}{|l|l|l|l|l|}
\hline \multicolumn{2}{|l|}{ Name of the format } & Frequency & Percent & $\begin{array}{c}\text { Cumulative } \\
\text { Percentage }\end{array}$ \\
\hline Super Market & Married & 54 & 63.5 & 63.5 \\
\cline { 2 - 5 } & Single & 31 & 36.5 & 100.0 \\
\cline { 2 - 5 } & Total & 85 & 100.0 & 100.0 \\
\hline Hyper Market & Married & 159 & 62.4 & 62.4 \\
\cline { 2 - 5 } & Single & 96 & 37.6 & 100.0 \\
\cline { 2 - 5 } & Total & 255 & 100.0 & 100.0 \\
\hline Departmental Store & Married & 111 & 55.5 & 55.5 \\
\cline { 2 - 5 } & Single & 89 & 44.5 & 100.0 \\
\cline { 2 - 5 } & Total & 200 & 100.0 & 100.0 \\
\hline
\end{tabular}

In the table 6 , it is found that in supermarket out of a total of 85 customers, 54 customers are married and 31 customers are found single. In hypermarket, it is found that out of a total of 255 customers, 159 are married and rests 96 are found to be single. In the departmental stores, I found that out of a total of 200 customers; 111 are found married and 89 are single.

\subsection{Customers Professional Category across Various Formats (Super Market, Hyper Market \& Departmental Stores)}

Table 7

\begin{tabular}{|c|c|c|c|c|}
\hline \multicolumn{2}{|c|}{ Name of the format } & Frequency & Percentage & $\begin{array}{l}\text { Cumulative } \\
\text { Percentage }\end{array}$ \\
\hline \multirow[t]{6}{*}{ Super Market } & Professional/Administrative & 28 & 32.9 & 32.9 \\
\hline & Academic & 09 & 10.6 & 43.5 \\
\hline & Student & 09 & 10.6 & 54.1 \\
\hline & Own Business & 20 & 23.5 & 77.6 \\
\hline & Others & 19 & 22.4 & 100.0 \\
\hline & Total & 85 & 100.0 & \\
\hline \multirow[t]{6}{*}{ Hyper Market } & Professional/Administrative & 121 & 47.5 & 47.5 \\
\hline & Academic & 18 & 7.1 & 54.5 \\
\hline & Student & 26 & 10.2 & 64.7 \\
\hline & Own Business & 41 & 16.1 & 80.8 \\
\hline & Others & 49 & 19.2 & 100.0 \\
\hline & Total & 255 & 100.0 & \\
\hline \multirow{6}{*}{$\begin{array}{l}\text { Departmental } \\
\text { Store }\end{array}$} & Professional/Administrative & 91 & 45.5 & 45.5 \\
\hline & Academic & 23 & 11.5 & 57.0 \\
\hline & Student & 9 & 4.5 & 61.5 \\
\hline & Own Business & 39 & 19.5 & 81.0 \\
\hline & Others & 38 & 19.0 & 100.0 \\
\hline & Total & 200 & 100.0 & \\
\hline
\end{tabular}

In the table 7, it is found that in supermarket 28 customers are in professional/ administrative types of jobs and 20 customers are running their own business. In this table it $\mathrm{s}$ also found that in case of hypermarket, 121 are professional/administrative types of jobs and 49 are in some or other types of jobs. In the departmental stores it is found that 91 customers are in professional/administrative types of jobs and it is followed by 39 customers are running their own business. 
4.8 Duration of Customers dealing across Various Formats (Super Market, Hyper Market \& Departmental Stores)

Table 8

\begin{tabular}{|c|c|c|c|c|}
\hline \multicolumn{2}{|c|}{ Name of the Format } & Frequency & cent & $\begin{array}{l}\text { Cumulative } \\
\text { Percentage }\end{array}$ \\
\hline \multirow{5}{*}{ Super Market } & \multirow{5}{*}{$\begin{array}{l}\text { Less than one yea } \\
\text { 1-to-2 year } \\
\text { 2-to-3 years } \\
\text { More than } 4 \text { years } \\
\text { Total }\end{array}$} & 32 & 37.6 & 37.6 \\
\hline & & 41 & 48.2 & 85.9 \\
\hline & & $\overline{11}$ & 12.9 & 98.8 \\
\hline & & 01 & 1.2 & 100.0 \\
\hline & & 85 & 100.0 & \\
\hline \multirow[t]{6}{*}{ Hyper Market } & \multirow{6}{*}{$\begin{array}{l}\text { Less than one year } \\
\text { 1-to-2 year } \\
\text { 2-to-3 years } \\
\text { 3-to-4 years } \\
\text { More than } 4 \text { years } \\
\text { Total }\end{array}$} & 66 & 25.9 & 25.9 \\
\hline & & 81 & 31.8 & 57.6 \\
\hline & & 70 & 27.5 & 85.1 \\
\hline & & 18 & 7.1 & 92.2 \\
\hline & & 20 & 7.8 & 100.0 \\
\hline & & 255 & 100.0 & \\
\hline \multirow{6}{*}{$\begin{array}{l}\text { Departmental } \\
\text { Store }\end{array}$} & \multirow{6}{*}{$\begin{array}{l}\text { Less than one year } \\
\text { 1-to-2 year } \\
\text { 2-to-3 years } \\
\text { 3-to-4 years } \\
\text { More than } 4 \text { years } \\
\text { Total }\end{array}$} & 62 & 31.0 & 31.0 \\
\hline & & 84 & 42.0 & 73.0 \\
\hline & & 37 & 18.5 & 91.5 \\
\hline & & 08 & 4.0 & 95.5 \\
\hline & & 09 & 4.5 & 100.0 \\
\hline & & 200 & 100.0 & \\
\hline
\end{tabular}

In the table 8 , it is found that in supermarket 41 customers are having dealing with the store between 1-to- 2 years and 32 customers are having dealing with the store from less than a year. In hypermarket, it is found that 81 customers are having dealing with the store between 1-to-2 years and 70 customers are visiting to the store between 2-to-3 years. In the departmental stores, it is found that 84 customers are having dealing 1-to-2 years and 62 are visiting to the store from last less than a year.

4.9 Comparison of Service Quality across the Various Formats (Supermarket, Hypermarket \& Departmental Stores)

Table 9

\begin{tabular}{|c|c|c|c|c|c|}
\hline \multicolumn{6}{|l|}{ Mean Values Across the Various Formats } \\
\hline & $\begin{array}{l}\text { Super } \\
\text { Market }\end{array}$ & $\begin{array}{l}\text { Hyper } \\
\text { Market }\end{array}$ & $\begin{array}{l}\text { Departmental } \\
\text { Store }\end{array}$ & F-Value & p-value \\
\hline This outlet has modern-looking equipment and fixtures & 3.7294 & 3.4549 & 3.5550 & 2.186 & .113 \\
\hline $\begin{array}{l}\text { Physical facilities in this outlet(Trial rooms and } \\
\text { restrooms) are attractive }\end{array}$ & 3.0706 & 3.4157 & 3.4300 & 4.115 & .017 \\
\hline $\begin{array}{l}\text { Materials associated with this outlet service (such as } \\
\text { shopping bags) are virtually appealing }\end{array}$ & 3.3529 & 3.6078 & 3.6400 & 2.317 & .100 \\
\hline $\begin{array}{l}\text { This outlet has clean and convenient physical facilities } \\
\text { (trial rooms, rest rooms etc.) }\end{array}$ & 3.5176 & 3.5843 & 3.7100 & 1.142 & .320 \\
\hline $\begin{array}{l}\text { The layout at this outlet makes it easier for me to find } \\
\text { what I need }\end{array}$ & 3.9882 & 3.5889 & 3.6599 & 3.485 & .017 \\
\hline $\begin{array}{l}\text { The store layout makes it easier to move around in the } \\
\text { store }\end{array}$ & 4.0706 & 3.6746 & 3.7677 & 4.169 & .016 \\
\hline
\end{tabular}




\begin{tabular}{|c|c|c|c|c|c|}
\hline $\begin{array}{l}\text { When this outlet promises to do something (such as } \\
\text { repairs, alterations) by a certain time, it will do so }\end{array}$ & 3.4235 & 3.3880 & 3.4308 & .109 & .897 \\
\hline $\begin{array}{l}\text { This outlet provides its services at the time it promises to } \\
\text { do so }\end{array}$ & 3.6000 & 3.4440 & 3.5692 & 1.108 & .331 \\
\hline This outlet performs the services right the first time & 3.6706 & 3.6588 & 3.6600 & .004 & .996 \\
\hline $\begin{array}{l}\text { This outlet has the merchandise available when the } \\
\text { customers want it }\end{array}$ & 3.5529 & 3.5160 & 3.6103 & .400 & .670 \\
\hline $\begin{array}{l}\text { The outlet has fast and error-free transactions relating to } \\
\text { billing, returns etc. }\end{array}$ & 3.7647 & 3.7059 & 3.7650 & .184 & .832 \\
\hline $\begin{array}{l}\text { Employees in this outlet has the knowledge to answer } \\
\text { customer's questions }\end{array}$ & 3.7176 & 3.6680 & 3.7653 & .482 & .618 \\
\hline $\begin{array}{l}\text { The behavior of employees in this outlet instills } \\
\text { confidence in customers }\end{array}$ & 3.6941 & 3.6508 & 3.6616 & .050 & .951 \\
\hline Customers feel safe in their transactions with this outlet & 4.2118 & 3.8745 & 4.0350 & 4.401 & .013 \\
\hline $\begin{array}{l}\text { Employees in this outlet give prompt service to the } \\
\text { customer's }\end{array}$ & 3.9059 & 3.7216 & 3.7800 & .930 & .395 \\
\hline $\begin{array}{l}\text { Employees in this outlet tell me exactly when services } \\
\text { will be performed }\end{array}$ & 3.8118 & 3.5913 & 3.7041 & 1.713 & .181 \\
\hline $\begin{array}{l}\text { Employees in this outlet respond to customer's requests } \\
\text { immediately }\end{array}$ & 3.9176 & 3.6349 & 3.6768 & 2.211 & .111 \\
\hline The outlet gives customers individual attention & 3.7529 & 3.5020 & 3.5179 & 1.720 & .180 \\
\hline $\begin{array}{l}\text { Employees in the outlet are consistently courteous with } \\
\text { the customers }\end{array}$ & 3.8000 & 3.6825 & 3.7980 & .788 & .455 \\
\hline The outlet willingly handles returns and exchanges & 3.6824 & 3.6280 & 3.7041 & .305 & .737 \\
\hline $\begin{array}{l}\text { When a customer has a problem, the outlet shows a } \\
\text { sincere interest in solving it }\end{array}$ & 3.6588 & 3.6364 & 3.7424 & .578 & .562 \\
\hline $\begin{array}{l}\text { Employees in this outlet are able to handle customer } \\
\text { complaints directly and immediately }\end{array}$ & 3.6118 & 3.5373 & 3.5250 & .204 & .815 \\
\hline The outlet offers high quality merchandise & 3.4471 & 3.3508 & 3.4526 & .565 & .569 \\
\hline $\begin{array}{l}\text { The outlet provides plenty of convenient parking for the } \\
\text { customers }\end{array}$ & 3.1529 & 3.5219 & 3.5309 & 3.184 & .042 \\
\hline $\begin{array}{l}\text { The outlet has operating hours convenient to all their } \\
\text { customers }\end{array}$ & 3.9059 & 3.7742 & 3.9053 & .911 & .403 \\
\hline The outlet accepts all major credit cards & 4.1529 & 4.1265 & 4.2222 & .540 & .583 \\
\hline
\end{tabular}

In the table 9 , it is found that there exist statistical differences among the following variables.

1. Physical facilities in this outlet(Trial rooms and restrooms) are attractive $(\mathrm{p}=.017)$

2. The layout at this outlet makes it easier for me to find what I need $\quad(p=.017)$

3. The store layout makes it easier to move around in the store $(p=.016)$

4. Customers feel safe in their transactions with this outlet( $\mathrm{p}=.013)$

5. The outlet provides plenty of convenient parking for the customers $\quad(p=.042)$

4.10 Comparison of Customer Satisfaction across the Various Formats (Supermarket, Hypermarket \& Departmental Stores)

Table 10

\begin{tabular}{|l|l|l|l|l|}
\hline $\begin{array}{l}\text { Super } \\
\text { Market }\end{array}$ & $\begin{array}{l}\text { Hyper } \\
\text { Market }\end{array}$ & $\begin{array}{l}\text { Departmental } \\
\text { Store }\end{array}$ & F & Sig. \\
\hline
\end{tabular}




\begin{tabular}{|c|c|c|c|c|c|}
\hline $\begin{array}{l}\text { I am extremely satisfied with overall dealing } \\
\text { with the outlet }\end{array}$ & 3.7294 & 3.6996 & 3.6701 & 0.179 & .836 \\
\hline $\begin{array}{l}\text { I am satisfied with my personal contact with the } \\
\text { staff }\end{array}$ & 3.7765 & 3.5415 & 3.5381 & 2.871 & 058 \\
\hline $\begin{array}{l}\text { I am satisfied with the product service quality of } \\
\text { the outlet }\end{array}$ & 3.9882 & 3.8221 & 3.7919 & 1.876 & 154 \\
\hline $\begin{array}{l}\text { I am satisfied with the product service quality of } \\
\text { the outlet }\end{array}$ & 3.9059 & 3.8200 & 3.7590 & 0.951 & 387 \\
\hline $\begin{array}{l}\text { The average score of overall evaluation of } \\
\text { Physical aspects, Reliability, Personal } \\
\text { Interaction, Problem-solving and Policy is } \\
\text { satisfactory }\end{array}$ & 3.8000 & 3.7352 & 3.8173 & 0.536 & 6 \\
\hline My store always meets my expectations & 3.7529 & 3.7312 & 3.7310 & .024 & 976 \\
\hline
\end{tabular}

From the table 10, the statistical significant difference is found among the following variables across the various formats

I am satisfied with my personal contact with the staff ( $\mathrm{p}=.058$ value)

Hence there exists a significant difference in personal contact with the staff among supermarket, hypermarket and departmental stores. The mean value was found higher in supermarket in comparison to hypermarket and departmental store. Hence we can conclude that personal contact with staff is better in supermarket in comparison to hypermarket and departmental store.

\subsection{Comparison of Behavioral Intentions across Various Formats (Supermarket,} Hypermarket \& Departmental Stores)

Table 11

\begin{tabular}{|c|c|c|c|c|c|}
\hline \multicolumn{6}{|l|}{ Type of the Formats } \\
\hline \multirow[t]{2}{*}{ Variables } & $\begin{array}{l}\text { Super } \\
\text { Market }\end{array}$ & $\begin{array}{l}\text { Hyper } \\
\text { Market }\end{array}$ & $\begin{array}{l}\text { Departmental } \\
\text { Stores }\end{array}$ & & \\
\hline & Mean & Mean & Mean & $\mathrm{F}$ & Sig. \\
\hline I would strongly recommend the outlet to customers & 3.8235 & 3.7200 & 3.8308 & .739 & .478 \\
\hline $\begin{array}{l}\text { I will encourage friends \& relatives to buy } \\
\text { from this outlet }\end{array}$ & 3.9882 & 3.8360 & 3.8872 & .702 & .496 \\
\hline $\begin{array}{l}\text { I would like to switch to another outlet that offers more } \\
\text { benefits }\end{array}$ & 3.5647 & 3.3944 & 3.4611 & .703 & .496 \\
\hline $\begin{array}{l}\text { I would like to switch to another outlet if I experience a } \\
\text { problem with this outlet }\end{array}$ & 3.7059 & 3.6449 & 3.7947 & .992 & .372 \\
\hline $\begin{array}{l}\text { I would like to continue with this outlet even } \\
\text { if the store increases the prices of its products }\end{array}$ & 3.0235 & 3.1474 & 3.0154 & .642 & .526 \\
\hline I would like to complain if I experience a problem & 3.5882 & 3.4567 & 3.6649 & 1.893 & .152 \\
\hline
\end{tabular}

From the table 11, by using one way ANOVA it is found that there is no statistical significant difference among the variables of behavioral intentions across the various formats like Super Market, Hypermarket and Departmental stores.

\section{Conclusions, Findings \& Implications of the Study}

1. In the analysis of super market, hypermarket and departmental stores, it was found from the frequency table that more number of customers belonging to age group 25 to 35 years and 
20 to 25 years were visiting to these stores. This young generation is spending more on consumption of their total income. So the managers of the Supermarkets, Hypermarkets and Departmental Stores should strategize their products and services to serve these consumers in meeting their present and future needs.

2. It was also found that more number of males was visiting these stores in comparison to females. Hence, managers need to avail those products and services which are being liked by the male consumers as well as by the female consumers. It was also found that these customers were belonging to the middle income group. Hence, these stores should provide them those categories of products and services which can meet their income level and can provide them high satisfaction level.

3. It was also found that people visiting to Supermarkets, Hypermarkets and Departmental Stores were dealing from 1 to 2 years and the customers who were having a dealing of 3 to 4 years or more were less in number. So the managers need to develop their strategies to retain the customers and to make them loyal in long run, in the Supermarkets, Hypermarkets and Departmental Stores.

4. It was also found that there existed a significant difference in the Physical Facility domain of Quality Scale among Supermarkets, Hypermarkets and Departmental Stores. The mean values made it clear that it was better in Departmental Stores being followed by Hypermarkets and Supermarkets. So the managers in the Hypermarkets and Supermarkets should improve physical facilities in their outlet to attain better quality and customer satisfaction. In addition to this, significant difference was found in the area of Layout in these stores. It was found better in Supermarkets being followed by Departmental Stores and Hypermarkets. So the managers of Departmental Stores and Hypermarkets need to improve their layout to achieve customer satisfaction.

5. It was also found that there existed a significant difference in personal contact with the staff among supermarket, hypermarket and departmental stores. The mean value was found higher in supermarket in comparison to hypermarket and departmental store. Hence we can conclude that personal contact with staff is better in supermarket in comparison to hypermarket and departmental store. Now better personal contact will lead to higher customer satisfaction level. So the managers working with hypermarket and departmental store need to improve the skills and knowledge of their staff to maintain better personal contact with the customers and it will bring better quality and customer satisfaction with the customers.

\section{References}

Caruana, A, Money, A. H; \& Berthon, P. R. (2000). Service Quality and Satisfaction; the Moderating Role of Value. European Journal of Marketing, 34.

Cronin, J. J., \& Taylor, S. A. (1992). Measuring Service Quality: A Reexamination and Extension. Journal of Marketing, 56, 55-58. http://dx.doi.org/10.2307/1252296

Dhabolkar, Pratibha A., Dayle, Thorpe \& Joseph O. Rentz (1996). A Measure of Service Quality for Retail Stores: Scale Development and Validation. Journal of Academy of Marketing Science, 24(1), 3-16. http://dx.doi.org/10.1007/BF02893933

Garvin, David A. (1988). Managing Quality: Strategic and Competitive Edge, in Dale H. Besterfield and Mary Besterfield (Eds). Total Quality Management (New York: Free Press/Prentice Hall. 


\section{Macrothink}

Business and Economic Research ISSN 2162-4860 2013, Vol. 3, No. 1

Leblanc, G. \& N. Nguyen (1988). Customers Perceptions of Service Quality in Financial Institutions. International Journal of Bank Marketing, 6(4), 127-139.

Lee, H; Lee, Y; \& Yoo D. (2000). The Determinants of Perceived Service Quality and its Relationship with Satisfaction. Journal of Service Marketing, 14(2), 217-231. http://dx.doi.org/10.1108/08876040010327220

Oliver, R. L. (1980). A Cognitive Model of the Antecedents and Consequences of Satisfaction Decisions. Journal of Marketing Research, 17 (Nov; 1980). http://dx.doi.org/10.2307/3150499

Parasuraman, A .L. L. Berry \& V. A. Zeithaml (1991). Refinement and Reassessment of the SERVQUAL Scale. Journal of Retailing, 67(4), 420-450.

Spreng, R. A. \& Mackoy, R. D. (1996). An Empirical Examination of a Model of Perceived Service Quality and Satisfaction, Journal of Retailing, 72(2), 201-214. http://dx.doi.org/10.1016/S0022-4359(96)90014-7

Zeithaml, V.A., Berry, L. L., \& Parasuraman, A. (1996). The Behavioral Consequences of Service Quality. Journal of Marketing, 60(2), 31-47. http://dx.doi.org/10.2307/1251929

Zeithaml, V. (1988). Consumer Perceptions of Price, Quality and Value: A Means-End Model and Synthesis of Evidence. Journal of Marketing, 52, 2-22. http://dx.doi.org/10.2307/1251446

\section{Copyright Disclaimer}

Copyright reserved by the author(s).

This article is an open-access article distributed under the terms and conditions of the Creative Commons Attribution license (http://creativecommons.org/licenses/by/3.0/). 